\title{
PENGEMBANGAN APLIKASI MOBILE DENGAN QT SDK: STUDI KASUS MONITORING RUANGAN MENGGUNAKAN KAMERA
}

\author{
Yansen; Agus Prijono \\ Jurusan Teknik Elektro, Fakultas Teknik, Universitas Kristen Maranatha \\ Jln. Prof. drg. Suria Sumantri, MPH. No. 65, Bandung \\ sen_0790@yahoo.com, agus.prijono@eng.maranatha.edu
}

\begin{abstract}
Nowadays, cell phones or mobile phones have become a multipurpose tool. The developers of mobile phone/smartphone have added an assortment of features and applications that are very useful for the users. Nokia provides the opportunity for application developers by providing developers such as Qt SDK. Application developers can use Qt SDK to design and create applications that can run on mobile phones based on Symbian. In this research Qt SDK was used to create applications for monitoring a room using a camera and display it on a Symbian-based smartphone. Research also used webcam7 software to monitor the camera and display it on PC screen. The Symbian used was Nokia E71. The camera used webcam M-Tech camera connected to the PC via USB cable, and internal webcam. Virtual routers were used to make the laptop into an access point. Virtual routers created using the netsh command was typed at the command prompt laptop. Symbian smartphone was connected to the wifi on the laptop. By accessing the IP of the laptop, display on a webcam has successfully been seen through a symbian smartphone monitoring application created using Qt SDK.
\end{abstract}

Keywords: Qt SDK, Symbian smartphone, webcam

\begin{abstract}
ABSTRAK
Saat ini, telepon seluler atau ponsel telah menjadi alat serbaguna. Para pengembang ponsel/smartphone telah menambahkan berbagai fitur dan aplikasi yang sangat berguna bagi pengguna. Nokia memberikan kesempatan bagi pengembang aplikasi dengan menyediakan pengembang seperti Qt SDK. Pengembang aplikasi dapat menggunakan Qt SDK untuk merancang dan membuat aplikasi yang dapat berjalan pada ponsel berbasis Symbian. Pada penelitian ini Qt SDK digunakan untuk membuat aplikasi untuk memantau ruangan dengan kamera dan menampilkannya pada smartphone berbasis Symbian. Penelitian juga menggunakan software webcam7 untuk memonitor kamera dan menampilkannya di layar komputer. Sistem operasi Symbian yang digunakan adalah Nokia E71. Kamera menggunakan webcam kamera M-Tech yang terhubung ke PC melalui kabel USB, dan webcam internal. Router virtual digunakan untuk membuat laptop menjadi jalur akses. Router virtual yang dibuat menggunakan perintah netsh diketik pada command prompt laptop. Smartphone Symbian terhubung ke wifi pada laptop. Dengan mengakses IP dari laptop, layar pada webcam telah berhasil dilihat melalui aplikasi monitoring smartphone symbian yang dibuat menggunakan Qt SDK.
\end{abstract}

Kata kunci: SDK Qt , Smartphone symbian, webcam 


\section{PENDAHULUAN}

Telepon genggam bukan lagi sekadar perangkat untuk bertelekomunikasi. Masyarakat sudah menggunakan telepon genggam tersebut untuk berbagai keperluan lainnya. Namun mayoritas pengguna telepon genggam di Indonesia tidak memaksimalkan semua fitur yang ditawarkan oleh sebuah telepon genggam. Dinamika jaringan sosial yang berkembang pesat di Indonesia juga memberikan kontribusi yang signifikan pada piranti telepon genggam. Maka dari itu, sangat disayangkan jika telepon genggam tidak dimaksimalkan kegunaannya.

Nokia memberikan kesempatan kepada pengembang aplikasi dengan memberikan software developer berupa Qt SDK. Pengembang aplikasi mobile dapat menggunakan Qt SDK untuk membuat aplikasi untuk dijalankan pada telepon genggam berbasis symbian. Hal tersebut dijadikan dasar dalam penelitian untuk membangun aplikasi mobile dengan Qt SDK dengan studi kasus monitoring ruangan menggunakan kamera. Qt SDK merupakan software yang akan digunakan pada symbian devices untuk membantu studi kasus memonitor ruangan menggunakan kamera yang dapat ditampilkan pada symbian devices tersebut.

Aplikasi ini bertujuan untuk dapat mengetahui keadaan suatu ruangan yang dipantau oleh kamera, yang kemudian dapat dipantau melalui smartphone berbasis symbian dengan aplikasi yang dibangun dari Qt SDK. Hal ini dapat membuat seorang pemantau tidak perlu menunggu di layar monitor tetapi dapat mengaksesnya melalui smartphone berbasis symbian tersebut. Masalah yang dibahas pada penelitian ini adalah bagaimana membangun aplikasi mobile dengan Qt SDK untuk memonitor ruangan menggunakan kamera. Sementara penelitian bertujuan untuk merancang dan membuat aplikasi mobile dengan Qt SDK untuk memonitor ruangan menggunakan kamera.

\section{Tinjauan Literatur}

\section{Nokia Qt SDK}

Qt Framework sejak lama digunakan untuk mengembangkan aplikasi lintas platform. Qt sendiri dibuat pada 1996 oleh perusahaan dari Swedia yang bernama Trolltech. Sifatnya yang lintas platform dapat membuat aplikasi yang berjalan di atas platform Windows, Linux, dan Mac. Dengan menggunakan Qt, kode yang sama dapat dijalankan pada target platform yang berbeda. Qt Framework sudah didesain sedemikian rupa sehingga mudah digunakan oleh developer tanpa harus mengorbankan fleksibilitas dan efisiensi. Qt mendukung pengembangan dengan dua bahasa utama, yaitu $C_{++}^{+}$dan java. Qt Framework memiliki koleksi class library yang lengkap dan konsisten. Class library tersebut berisi semua function yang dibutuhkan untuk mengembangkan aplikasi. Qt Framework membantu mengurangi pekerjaan developer dengan meningkatkan produktivitas penulisan kode.

Beberapa aplikasi yang dikembangkan dengan menggunakan Qt Framework di antaranya Google earth map application, Skype telephony application, VLC media player, KDE desktop environment. Qt juga digunakan pada berbagai perangkat elektronik dan aplikasi industri, sebagai contoh adalah mobile transportation system yang dibuat oeh Volvo, MeVislab digital imaging platform, dan Realflow visual effect application pada industri dunia hiburan.

Pada 2008 Nokia mengakuisisi Trolltech untuk memperlancar strategi pengembangan aplikasi lintas platform. Saat ini strategi Nokia adalah memfokuskan teknologi pengembangan aplikasi mobile pada Qt sebagai single app development framework. Untuk platform mobile, Qt mendukung beberapa sistem operasi di antaranya Symbian S60, Maemo, Symbian^3, dan Meego. Sedangkan untuk platform desktop, Qt mendukung sistem operasi Windows, Linux, dan Mac seperti ditunjukkan pada Gambar 1. 


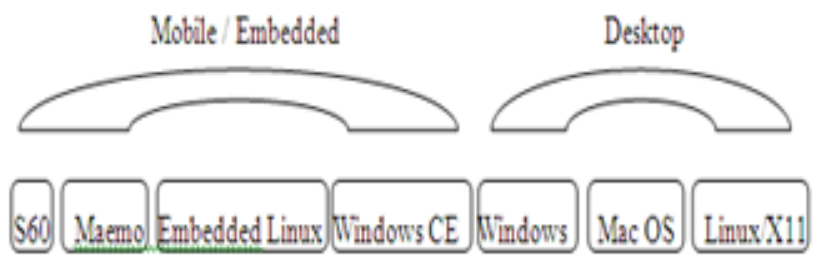

Gambar 1 Sistem Operasi yang didukung Qt

(Sumber: Kurniawan, 2011)

Dengan didukungnya pengembangan berbasis symbian 560 dan Symbian^3, maka pengembang Qt dapat membuat aplikasi yang ditujukan untuk sekitar 80 juta pengguna symbian devices. Nokia mempermudah pengembangan aplikasi mobile dengan menyediakan Nokia Qt SDK yang berisi class library, IDE (Qt Creator), dan Qt Simulator.

Qt SDK 1.1 mempunyai beberapa API generasi baru yang dapat digunakan untuk mengembangkan aplikasi berbasis Symbian, Maemo, dan Meego. Beberapa API generasi baru tersebut di antaranya: (1) Qt Quick adalah teknologi antarmuka yang memudahkan para pengembang untuk membuat desain antarmuka (UI) yang menarik dan dapat memberikan pengalaman lebih kepada user tanpa perlu mengetahui pemrograman $C++$. Qt Quick dapat dengan mudah digunakan oleh designer maupun developer untuk membuat antarmuka yang dinamis dan atraktif menggunakan Qt designer atau dengan menuliskan kode QML. (2) Qt 4.7 API merupakan kumpulan library yang lengkap dan memiliki performa yang bagus untuk mengembangkan aplikasi.

Qt Mobility 1.1 API: kumpulan library yang digunakan untuk mengintegrasikan aplikasi dengan hardware pada mobile device seperti camera, calendar, gallery, location, navigation, dan mapping.

\section{Qt Creator IDE (Integrated Development Environment)}

Berikut ini (Gambar 2) adalah tampilan dari QT Creator.

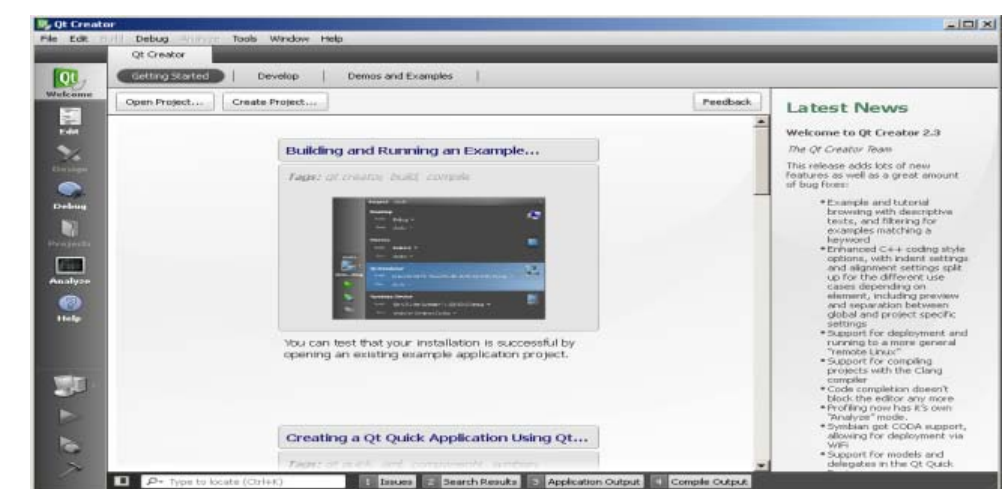

Gambar 2 Qt Creator

Pada mode welcome, dapat dilakukan: (1) membuka tutorial dan contoh project; (2) melihat tips dan hints penggunaan Qt Creator; (3) membuat dan membuka project; (4) mengirim feedback ke development team; (5) membuka recent sessions dna projects; (6) membaca berita dari Qt labs; (7) meminta bantuan (support). 
berikut.

Bagian Project Contents berisi semua file project yang telah dibuat seperti pada Gambar 3

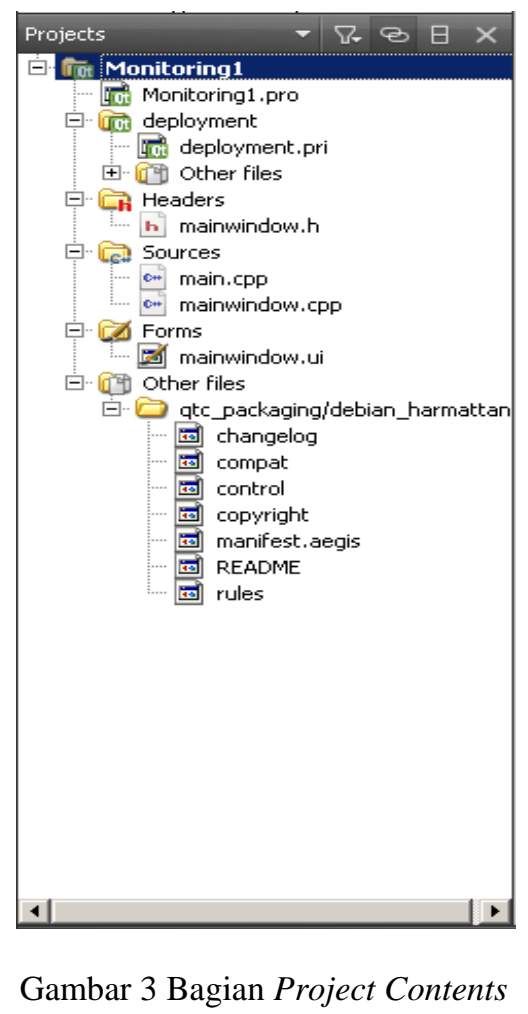

Pada sidebar menu, dapat dilakukan: (1) projects, menampilkan semua project pada sesi yang aktif; (2) file system, menampilkan isi file pada sebuah direktori pada sistem operasi yang diinstal; (3) bookmarks, menampilkan semua bookmark yang ada pada sesi aktif; (4) open documents, menampilkan file yang terbuka.

Sedangkan pada bagian output di bagian bawah editor, dapat melihat output sebagai berikut: build issues: menampilkan hasil dari proses build; search results: menampilkan hasil pencarian; application output: menampilkan hasil dari aplikasi yang dibuat; compile Output: menampilkan hasil proses kompilasi

\section{Qt Webkit Module}

Webkit module adalah porting dari open source webkit engine yang digunakan dalam browser Safari pada Apple. Engine untuk rendering ini juga digunakan pada banyak browser lain seperti Google Chrome dan Android browser. Webkit adalah rendering engine yang dapat me-render tag HTML pada layar sesuai keinginan pengguna. Webkit juga memiliki JavaScript engine untuk mengeksekusi script dari JavaScript di klien.

Integrasi webkit pada Qt meliputi class untuk integrasi web dengan Qt dan Qt dengan web. Webkit module dapat menangani kebutuhan standar dari browser modern seperti: (1) HTML 4.01 dan HTML 5 (2D Canvas, Audio/Video Playback, offline app, webworkers (thread), storage, dan SQL database); (2) CSS1, CSS2, dan CSS3 (background, border, dan fonts; serta transformation 2D dan 3D). Jenis-jenis class yang ada pada modul Qt webkit ditunjukkan pada Tabel 1 sebagai berikut. 
Tabel 1 Jenis-jenis Class pada Modul Qt Webkit

\begin{tabular}{|c|c|}
\hline Jenis Class & Penjelasan class \\
\hline QWebElement & $\begin{array}{l}\text { Class yang digunakan untuk } \\
\text { mengakses dan mengedit } \\
\text { QWebFrame DOM elemen } \\
\text { dengan menggunakan jQuery- } \\
\text { like API }\end{array}$ \\
\hline $\mathrm{Q}$ WebFrame & $\begin{array}{l}\text { Data object yang } \\
\text { merepresentasikan frame pada } \\
\text { web page }\end{array}$ \\
\hline $\mathrm{QWebHistory}$ & $\begin{array}{l}\text { History dari link yang } \\
\text { dikunjungi, yang berhubungan } \\
\text { dengan } \mathrm{QWebPage}\end{array}$ \\
\hline $\mathrm{QWebHistoryItem}$ & $\begin{array}{l}\text { Object yang merepresentasikan } \\
\text { sebuah link yang dikunjungi } \\
\text { pada } \mathrm{Q} \text { WebHistory }\end{array}$ \\
\hline QWebPage & $\begin{array}{l}\text { Data object yang } \\
\text { merepresentasikan web page }\end{array}$ \\
\hline $\mathrm{QWebSettings}$ & $\begin{array}{l}\text { Data object yang berisi } \\
\text { pengaturan yang digunakan oleh } \\
\text { QWebFrame atau QWebPage }\end{array}$ \\
\hline $\mathrm{Q}$ WebView & $\begin{array}{l}\text { Widget yang digunakan untuk } \\
\text { menampilkan QWebPage }\end{array}$ \\
\hline
\end{tabular}

(Sumber: Kurniawan, 2011)

Hubungan antarclass webkit tersebut dapat dilihat pada Gambar 4 berikut.

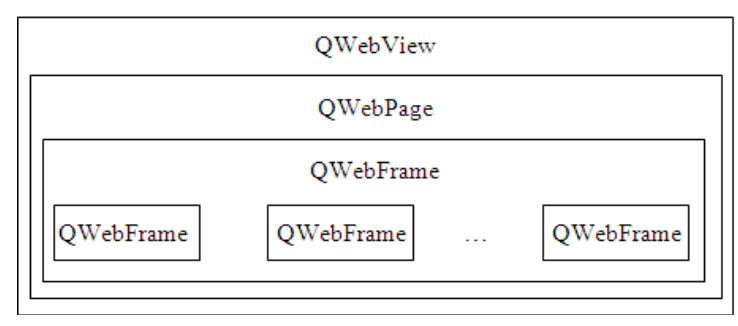

Gambar 4 Skema Hubungan Antarclass Webkit (Sumber: Kurniawan, 2011)

Untuk dapat menggunakan modul webkit pada aplikasi Qt yang dibuat, diperlukan penambahan library webkit pada file .pro.

Komunikasi wireless LAN (dalam Ambarwaty, 2011)

Wireless LAN adalah suatu jaringan area lokal nirkabel yang menggunakan gelombang radio sebagai media transmisinya. Pada umumnya WLAN digunakan sebagai titik distribusi di tingkat pengguna akhir melalui sebuah atau beberapa perangkat yang disebut dengan access point (AP), berfungsi mirip hub dalam terminologi jaringan kabel Ethernet. WLAN dimaksudkan sebagai solusi alternatif media untuk menjangkau pengguna yang tidak terlayani oleh jaringan kabel, serta untuk mendukung pengguna yang sifatnya bergerak atau berpindah-pindah (mobilitas).

Frekuensi yang kini umum dipergunakan untuk aplikasi WLAN adalah $2.4 \mathrm{Ghz}$ dan $5.8 \mathrm{Ghz}$ yang secara internasional dimasukkan ke dalam wilayah licence exempt (bebas lisensi) dan dipergunakan bersama oleh publik (frequency sharing). Teknologi yang digunakan untuk WLAN mayoritas menggunakan standar IEEE 802.1 (a/b/g). Perbedaan antarstandar ini adalah pada modulasi 
transmisinya yang menentukan kapasitas layanan yang dihasilkan. Pada standar 802.11b, kapasitas maksimalnya 11 Mbps, 802.11g dapat mencapai 20 Mbps keduanya bekerja di frekuensi 2.4 Ghz. Sementara standar 802.11a bekerja pada frekuensi 5.8 Ghz. Karena lebar pita frekuensi yang lebih luas dan modulasi yang lebih baik, maka perangkat yang berbasis standar ini mampu melewatkan data hingga kapasitas 54 dan 108 Mbps dan menampung jumlah pengguna lebih banyak.

Wireless local area network (WLAN) adalah sistem komunikasi data yang fleksibel yang dapat diimplementasikan sebagai perpanjangan atau pun sebagai alternatif pengganti untuk jaringan kabel LAN. Dengan menggunakan teknologi frekuensi radio, wireless LAN mengirim dan menerima data melalui media udara, dengan meminimalisasi kebutuhan akan sambungan kabel. Dengan begitu, wireless LAN telah dapat mengkombinasikan antara konektivitas data dengan mobilitas user. Dengan wireless LAN, user bisa membagi akses informasi tanpa harus mencari tempat sebagai sambungan kabel ke jaringan, dan network manager bisa menset up atau menambah jaringan tanpa harus melakukan instalasi atau pun penambahan kabel.

Webcam (dalam Etalaseilmu, 2009)

Webcam adalah kamera video sederhana berukuran relatif kecil. Webcam sering digunakan untuk konferensi video jarak jauh atau sebagai kamera pemantau. Webcam pada umumnya tidak membutuhkan kaset atau tempat penyimpanan data. Data hasil perekaman yang didapat langsung ditransfer ke komputer.

Jenis-jenis webcam dibagi menjadi: pertama, serial and parallel port Webcam. WebCam jenis ini sudah terlalu tua dan jarang ditemukan lagi karena sudah tidak ada yang memproduksi. Selain itu, kamera jenis ini menghasilkan kualitas gambar yang rendah dan frame rate yang rendah pula. Kedua, USB WebCam. WebCam jenis ini merupakan solusi bagi pengguna baru dan amatir. WebCam jenis ini mendukung fasilitas PnP (Plug and Play) dan dapat dihubungkan ke port USB tanpa harus mematikan computer. Namun syaratnya sistem operasi komputer harus mendukung fasilitas USB port.

Webcam yang digunakan pada penelitian ini adalah webcam internal dari laptop yang memiliki resolusi 1.3 MP dan USB webcam M-Tech 5 MP dengan spesifikasi sebagai berikut (vilani, n.d.): automatic with balance, automatic color compensation, manual snapshot, webcam resolution up to $5 \mathrm{MP}$.

\section{Virtual Router (dalam CodePlex, n.d.)}

Virtual router merupakan teknologi yang dapat membuat $P C$ atau laptop menjadi access point. Dalam penelitian ini, virtual router digunakan untuk dapat melakukan koneksi LAN secara wireless. Virtual router tersebut dibuat dengan cara mengetikkan perintah netsh pada command prompt. Hal ini dapat dilakukan jika user menggunakan run as administrator pada command prompt tersebut. Perintah yang diketikkan adalah: "netsh wlan set hostednetwork mode=allow ssid=test key=password". Kemudian buka network and sharing center, pilih mode koneksi ke internet, enable sharing dan memilih special 'hosted' interface atau wireless connection. Kemudian mengetikkan kembali perintah ini: netsh wlan start hostednetwork. Lalu koneksikan wifi dengan hostednetwork yang telah dibuat kemudian aplikasi monitoring pada smartphone dijalankan.

XAMPP (dalam Wikipedia, n.d.)

XAMPP adalah perangkat lunak bebas yang mendukung banyak sistem operasi, merupakan kompilasi dari beberapa program. Fungsinya adalah sebagai server yang berdiri sendiri (localhost), yang terdiri atas program Apache HTTP Server, MySQL database, dan penerjemah bahasa yang ditulis dengan bahasa pemrograman PHP dan Perl. Nama XAMPP merupakan singkatan dari X (empat sistem operasi apapun), Apache, MySQL, PHP dan Perl. XAMPP merupakan web server yang mudah 
digunakan yang dapat melayani tampilan halaman web yang dinamis. Program ini dapat dijalankan pada beberapa sistem operasi seperti Windows, Linux, Mac OS, dan Solaris. Apache merupakan aplikasi web server yang berfungsi untuk menghasilkan halaman web yang benar kepada user berdasarkan kode PHP yang dituliskan oleh pembuat halaman web.

MySQL merupakan aplikasi database server. Perkembangannya disebut SQL yang merupakan kepanjangan dari Structured Query Language. SQL merupakan bahasa terstruktur yang digunakan untuk mengolah database. MySQL dapat digunakan untuk membuat dan mengelola database beserta isinya. Kita dapat memanfaatkan MySQL untuk menambahkan, mengubah, dan menghapus data yang berada dalam database.

Bahasa pemrograman PHP merupakan bahasa pemrograman untuk membuat web yang bersifat server-side scripting. PHP memungkinkan untuk membuat halaman web yang bersifat dinamis. Sistem manajemen basis data yang sering digunakan bersama PHP adalah MySQL, namun PHP juga mendukung sistem manajemen database Oracle, Microsoft Access, Interbase, d-base, PostgreSQL, dan sebagainya.

Perl adalah singkatan dari Practical Extraction and Report Language. Bahasa pemrograman ini diciptakan oleh Larry Wall pada 1986 yang awalnya digunakan sebagai perangkat lunak yang digunakan untuk menulis program di lingkungan UNIX. Terdapat beberapa bagian penting pada XAMPP yang biasa digunakan pada umumnya, yaitu: htdoc adalah folder tempat meletakkan berkasberkas yang akan dijalankan, seperti berkas PHP, HTML, dan skrip lain; phpMyAdmin merupakan bagian untuk mengelola basis data MySQL yang ada di komputer. Untuk membukanya, buka browser lalu ketikkan alamat http://localhost/phpMyAdmin, maka akan muncul halaman phpMyAdmin; control panel yang berfungsi untuk mengelola layanan (service) XAMPP, seperti menghentikan (stop) layanan, ataupun memulai (start).

\section{METODE}

Rancangan sistem pada tahapan dalam pengerjaan penelitian dijelaskan sebagai berikut. Pertama, pemahaman studi literatur yang berkaitan dengan Qt SDK, Smartphone Symbian, komunikasi wireless LAN, webcam, dan tentang konsep localhost XAMPP. Kedua, pengumpulan dan analisis data. Pengumpulan dan analisis data yang dibutuhkan dalam perancangan sebuah aplikasi menggunakan software Qt SDK. Ketiga, perancangan aplikasi monitoring dengan Qt SDK. Pada tahap ini dirancang aplikasi untuk memonitor dengan menggunakan webcam yang dapat diakses melalui Smartphone berbasis Symbian. Keempat, implementasi pembuatan aplikasi monitoring. Tahapan ini merealisasikan aplikasi pada tahapan sebelumnya ke Smartphone symbian menjadi sebuah aplikasi yang dapat memonitor dengan menggunakan webcam. Kelima, uji coba dan evaluasi. Uji coba aplikasi monitoring yang telah diimplementasikan untuk mengidentifikasi masalah-masalah yang mungkin muncul dalam membandingkan webcam 1.3 MP dan 5 MP.

\section{HASIL DAN PEMBAHASAN}

Sistem ini menggunakan 4 software yaitu Qt SDK, webcam7, XAMPP, dan Nokia PC Suite, serta memerlukan dua buah kamera webcam. Dalam penelitian ini, kamera yang digunakan berupa webcam M-TECH 5MP dan webcam internal 1.3MP. Aplikasi monitoring dibuat menggunakan Qt SDK untuk memonitor suatu ruangan yang dipantau dengan webcam. Webcam tersebut dipantau melalui software webcam7. Smartphone symbian yang digunakan disini adalah Nokia E71. Beberapa hal yang perlu diinstal pada Smartphone tersebut adalah Qt SDK, Qt Mobility, Qt Webkit, dan TRK 
yang sesuai dengan versi symbian yang digunakan (Ambarwaty, 2011). Karena aplikasi yang dibuat akan dijalankan pada perangkat mobile, Qt Mobility diperlukan. Qt Webkit diperlukan karena aplikasi monitoring menggunakan QWebView untuk menampilkan hasil pantauan webcam melalui WLAN. TRK merupakan aplikasi yang diperlukan untuk menginstalkan aplikasi yang dibuat Qt ke dalam Smartphone yang digunakan. Nokia E71 merupakan symbian S60 $3^{\text {rd }}$ edition. Virtual router dibuat dengan mengetikkan perintah netsh pada command prompt. Halaman web yang digunakan untuk menampilkan pantauan webcam, dibuat terlebih dahulu pada $2 \mathrm{html}$ yang terpisah untuk source webcam1 dan source webcam2. XAMPP digunakan sebagai web server yang akan menyimpan halaman tersebut. Ide dasarnya adalah dengan mengakses halaman web dari XAMPP pada PC yang terhubung dengan webcam tersebut menggunakan koneksi wifi dari smartphone yang digunakan melalui aplikasi monitoring yang telah dibuat dengan Qt SDK. Sistem ini masih bersifat local area network (LAN).

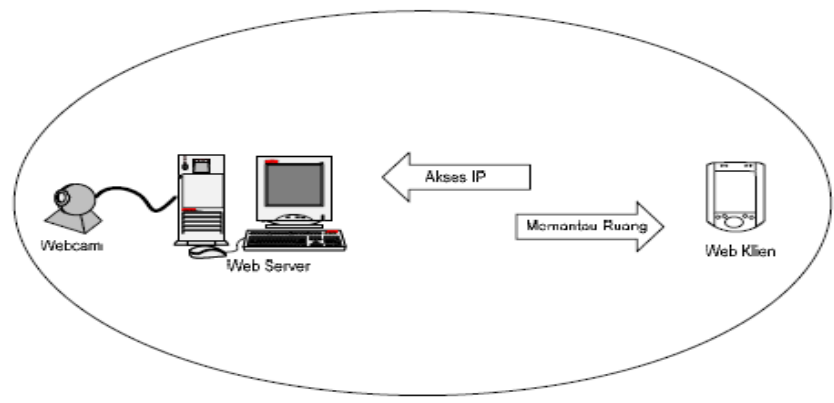

Gambar 5 Diagram perancangan sistem

\section{Pembuatan Aplikasi Monitoring}

Aplikasi monitoring dibuat menggunakan Qt Creator pada Qt. Pada aplikasi monitoring ini, diperlukan 2 buah QRadioButton, sebuah QPushButton, dan sebuah QWebView. QRadioButton diperlukan untuk memilih webcam mana yang akan diakses. QPushButton diperlukan untuk melakukan switch antar webcam. QWebView diperlukan sebagai halaman untuk menampilkan hasil pantauan webcam secara realtime. QRadioButton, QPushButton dan QWebView diletakkan pada form seperti pada Gambar 6. Tampilan dari form setelah ditambahkan kontrol di atas adalah sebagai berikut.

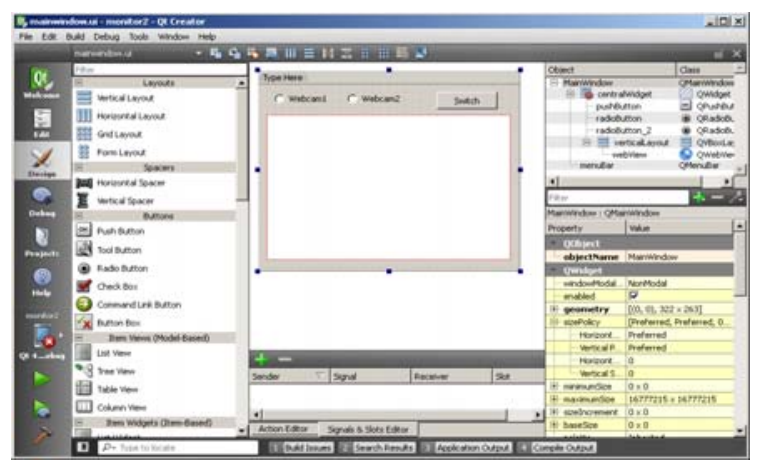

Gambar 6 Tampilan Form pada Qt Creator

\section{Realisasi Aplikasi Monitoring ke Smartphone Symbian}

Untuk dapat menggunakan aplikasi yang telah dibuat tersebut pada smartphone symbian, maka aplikasi tersebut harus diinstal ke smartphone yang digunakan melalui kabel USB. Qt SDK, Qt Mobility, Qt Webkit, dan TRK diinstal ke smartphone tersebut melalui Nokia PC Suite. Aplikasi 
monitoring yang telah dibuat, diinstal ke smartphone symbian tersebut. Pada OS Symbian, aplikasi yang dibuat harus di-package dengan format spesifik, yaitu .SIS (Software Installation Script) file. SIS file berisi data biner dari aplikasi, ikon, dan file yang lain yang dibutuhkan oleh aplikasi.

\section{Webcam7 (dalam WebcamXP, n.d.)}

Webcam7 merupakan salah satu software untuk melakukan monitoring menggunakan webcam. Webcam yang digunakan diletakkan di posisi yang ingin dipantau dan dihubungkan dengan PC, maka driver akan terinstal secara otomatis sehingga PC dapat mengenali webcam tersebut. Webcam7 dijalankan dan source webcam yang akan digunakan dikoneksikan seperti ditunjukkan pada Gambar 7.

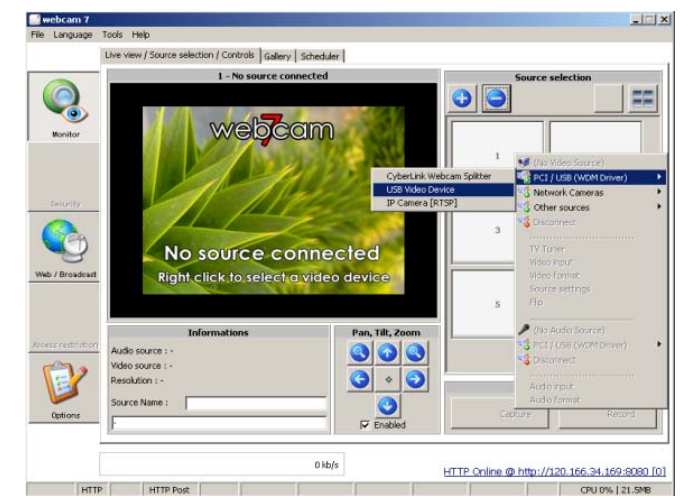

Gambar 7 Tampilan software Webcam7 saat memilih source

\section{XAMPP}

Xampp digunakan sebagai webserver yang menyimpan file html yang digunakan pada penelitian ini. File html yang dibuat adalah webcam1.html untuk mengakses webcam yang pertama dan webcam2.html untuk mengakses webcam yang kedua. Pada penelitian ini digunakan $2 \mathrm{html}$ untuk switch dari webcam pertama ke webcam kedua dan juga sebaliknya. Halaman web yang telah dibuat disimpan pada folder htdocs pada XAMPP. Agar halaman web tersebut dapat diakses maka XAMPP harus diaktifkan dengan cara start pada xampp-control.exe seperti pada Gambar 8 berikut.

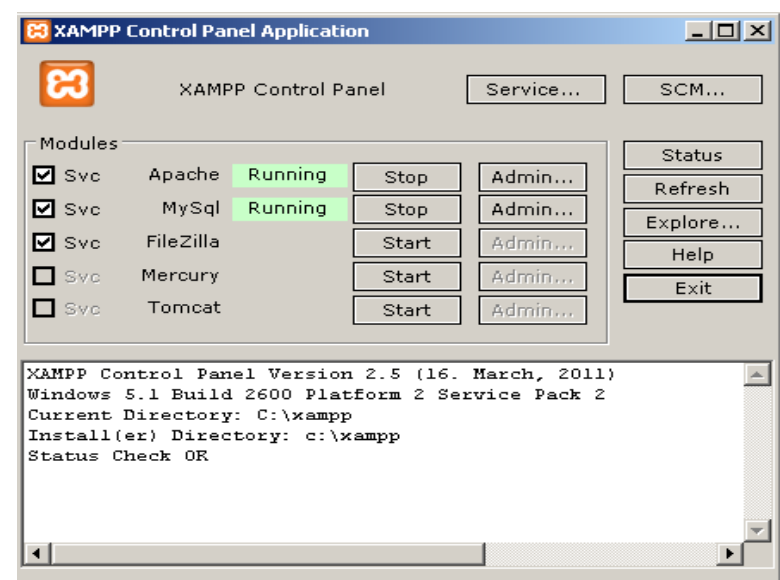

Gambar 8 XAMPP Control Panel 
Aplikasi monitoring yang telah dibuat dan diinstal pada smartphone diuji untuk mengakses webcam dengan resolusi pixel 1.3 MP (internal) dan 5 MP. Data yang diamati berupa rata-rata jumlah frame yang dikirim tiap detik (FPS), dan rata-rata besar data yang dikirim tiap detik seperti ditunjukkan pada Gambar 9. Data yang diambil dilakukan dengan kondisi webcam ditutup.

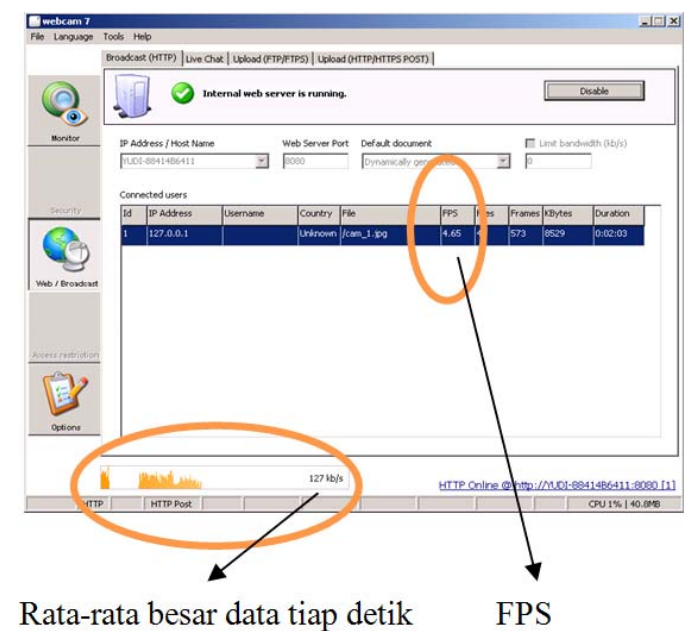

Gambar 9 Data Pengamatan

\section{Webcam 1.3 MP (Internal)}

Berikut merupakan grafik pengujian rata-rata besar data yang dikirim tiap detik dilakukan 5 kali pada 30 detik pertama koneksi pada webcam 1.3 MP.

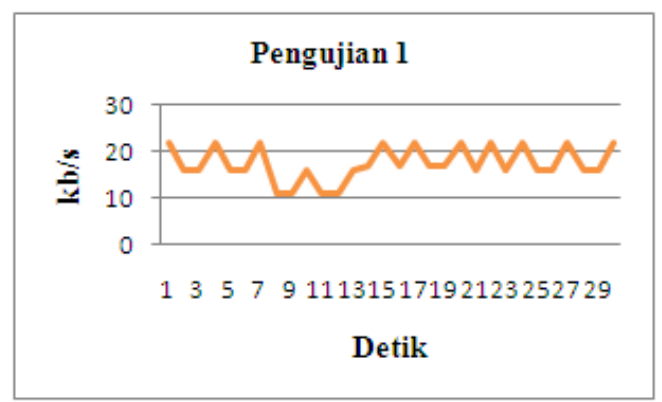

Gambar 10 Grafik Pengujian 1 (Besar Data tiap Detik) Webcam 1.3 MP

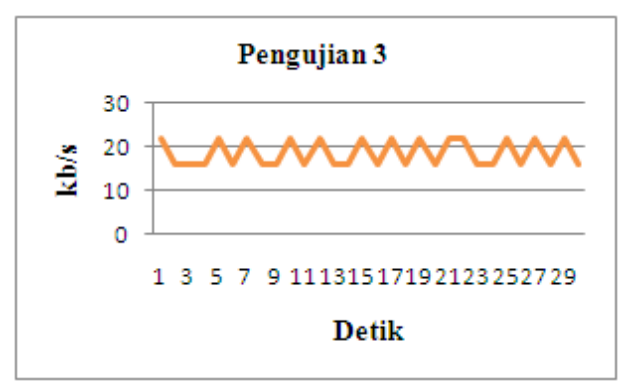

Gambar 12 Grafik Pengujian 3

(Besar Data tiap Detik) Webcam 1.3 MP

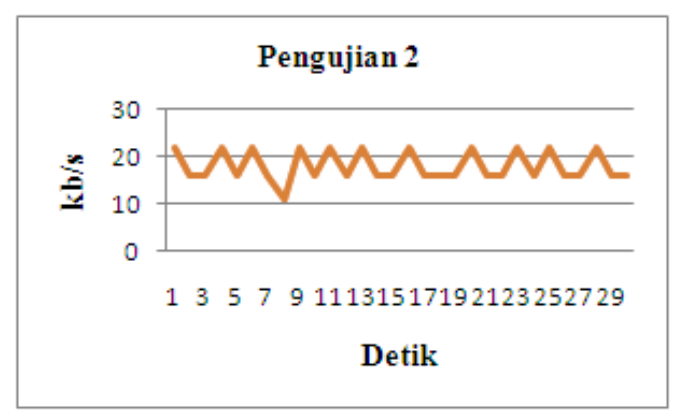

Gambar 11 Grafik Pengujian 2 (Besar Data tiap Detik) Webcam 1.3 MP

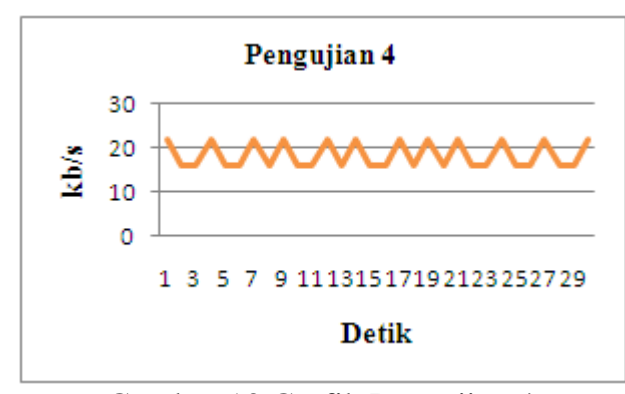

Gambar 13 Grafik Pengujian 4 (Besar Data tiap Detik) Webcam 1.3 MP 


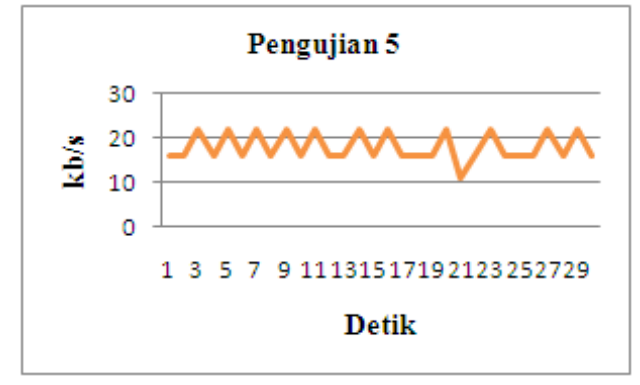

Gambar 14 Grafik Pengujian 5

(Besar Data tiap Detik) webcam 1.3 MP

\section{Webcam 5 MP}

Berikut merupakan grafik pengujian rata-rata besar data yang dikirim tiap detik dilakukan 5 kali pada 30 detik pertama koneksi pada webcam 5 MP:

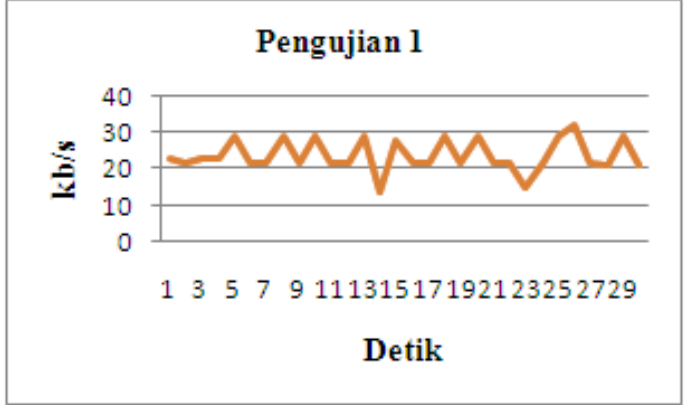

Gambar 15 Grafik Pengujian 1

(Besar Data tiap Detik) Webcam 5 MP

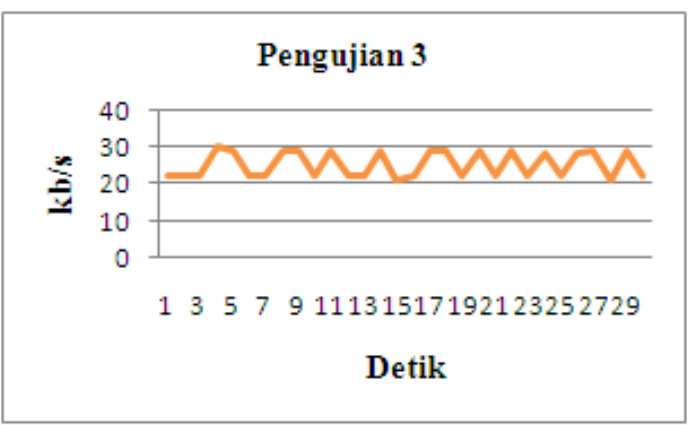

Gambar 17 Grafik Pengujian 3 (Besar Data tiap Detik) Webcam 5 MP

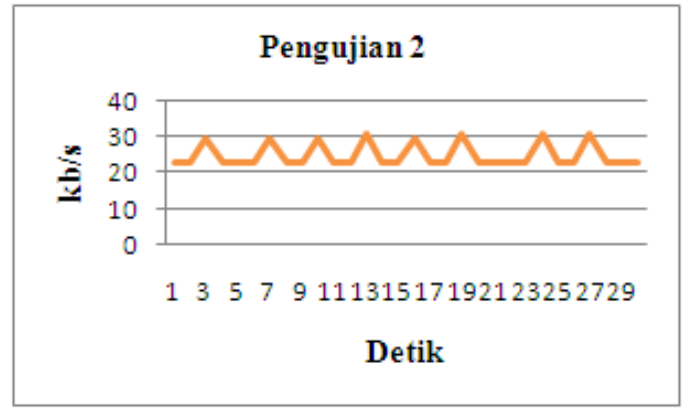

Gambar 16 Grafik Pengujian 2

(Besar Data tiap Detik) Webcam 5 MP

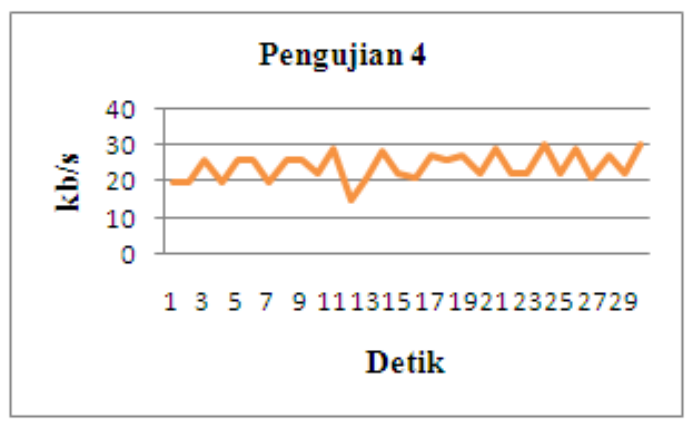

Gambar 18 Grafik Pengujian 4 (Besar Data tiap Detik) Webcam 5 MP

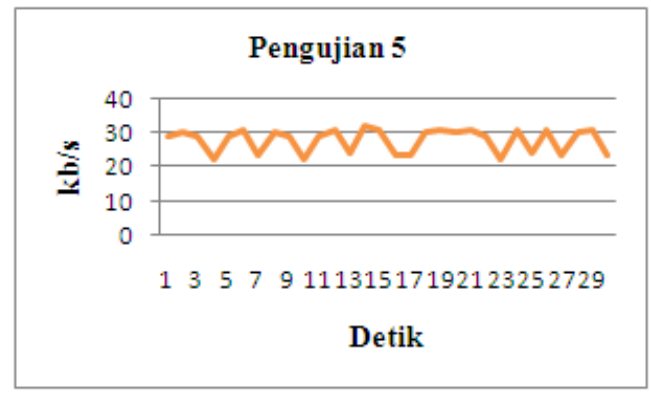

Gambar 19 Grafik Pengujian 5 (Besar Data tiap Detik) Webcam 5 MP 
Dari pengujian yang dilakukan pada 2 buah webcam dengan memantau objek yang sama intensitas warna dan pencahayaannya, diperoleh data sebagai berikut. Pertama, pada webcam 1.3 MP (internal), yaitu: rata-rata 3.20 FPS dan rata- rata besar data yang dikirim sebesar $18.11 \mathrm{~kb} / \mathrm{s}$. Kedua, pada webcam 5 MP, yaitu: rata-rata 3.33 FPS dan rata-rata besar data yang dikirim sebesar $25.20 \mathrm{~kb} / \mathrm{s}$.

\section{SIMPULAN}

Dengan memerhatikan data pengamatan dan analisis, dapat disimpulkan sebagai berikut. Pertama, aplikasi mobile dengan studi kasus monitoring ruangan menggunakan kamera berhasil direalisasikan menggunakan Qt SDK ke dalam smartphone berbasis symbian. Kedua, FPS tidak dipengaruhi oleh resolusi pixel dari webcam yang digunakan, sehingga berapapun resolusi pixel yang digunakan, FPS akan relatif sama. Ketiga, resolusi pixel webcam yang digunakan memengaruhi ratarata besar data yang dikirim tiap detik, akan relatif lebih besar pada resolusi pixel webcam yang lebih besar dibandingkan dengan resolusi pixel webcam yang lebih kecil.

Saran yang dapat diberikan untuk perbaikan dan pengembangan dari penelitian ini adalah kamera webcam dapat digerakkan dan dapat melakukan zoom in dan zoom out dan menggunakan koneksi Internet dengan IP public agar dapat diakses di lokasi mana pun.

\section{DAFTAR PUSTAKA}

Ambarwaty, S. (2011, 31 Oktober). Teknologi Wireless LAN (WLAN). Diakses 2013 dari http://shintaambarwaty.blogspot.com/2011/10/teknologi-wireless-lan-wlan.html

CodePlex. (n.d.). Virtual Router - Wifi Hot Spot for Windows 8, Windows 7 and 2008 R2. Last Edited by Pietschmann, C., Feb 11, 2013 at 4:16 AM. Diakses 2013 dari www.virtualrouter.codeplex.com/discussions/266860.

Etalaseilmu. (2009, 12 November). Web Camera. Diakses 2013 dari http://etalaseilmu.wordpress.com/2009/11/12/web-camera/.

Kurniawan, E. (2011). Membangun Aplikasi Mobile dengan Qt SDK. Yogyakarta: Andi.

Vilani. (n.d). Diakses 2013 dari www.vilani.web.id/93-pc-camera-m-tech-5mp.html

WebcamXP. (n.d.). WebcamXP. Diakses 2013 dari http://www.webcamxp.com/home.aspx.

Wikipedia. (n.d.). XAMPP. Diakses 2013 dari www.id.m.wikipedia.org/wiki/Xampp. 